\title{
Functional Foods in Times of Pandemic: Mini review
}

\author{
Estrada-Fernández Ana Guadalupe and Mendoza-Mendoza Bethsua* \\ Instituto Tecnológico Superior del Oriente del Estado de Hidalgo, México
}

*Corresponding author: Mendoza-Mendoza Bethsua, Instituto Tecnológico Superior del Oriente del Estado de Hidalgo, Carretera Apan-Tepeapulco km 3.5, Colonia Las Peñitas, Apan, Hidalgo, México.

To Cite This Article: Estrada-Fernández Ana Guadalupe, Mendoza-Mendoza Bethsua, Functional Foods in Times of Pandemic: Mini review. 2020 10(6). AJBSR.MS.ID.001580. DOI: 10.34297/AJBSR.2020.10.001580.

Received: 眥 November 17, 2020; Published: 漈 November 23, 2020

Keywords: COVID-19; Pandemic; Health problems; Functional foods; Bioactive compounds

Abbreviations: SARS-Cov-2: Severe Acute Respiratory Syndrome Coronavirus-2; PUFAS: Polyunsaturated Fatty Acids; SFA: Saturated Fatty Acids; MD: Mellitus Diabetes

\section{Introduction}

In 2020, the world was surprised by the attack of the SARS-CoV-2 virus, which causes the acute respiratory syndrome COVID-19, this led to the establishment of social isolation as the main measure to stop contagion, causing an increase in physical inactivity, poor diet and sleep quality, raising health problems that already existed before the pandemic, such as overweight, obesity, diabetes, cardiovascular diseases and even depression of the immune system [1]. The use of functional foods is considered a good option in times of pandemic. A food can be considered functional if it is shown to have a function, beyond nutritional effects, to improve health status and/ or reduce the risk of disease [2]. While natural foods, such as strawberries or onions, have been defined as functional foods, only foods that undergo processing are considered functional foods. Thus, several methods to obtain functional foods include the addition or removal of a component, which allows the food industry to develop new value-added products in the market [3]. Therefore, the objective of this review is to show the use of some foods that have been exploited as a source of bioactive compounds in order to be used in the creation of functional foods.

\section{Aguamiel}

The "aguamiel" is the sap of agave, obtained from plants between 8 and 10 years old. The Agaves used for its production are
Agave americana, Agave atrovirens, Agave ferox, Agave mapisaga and Agave salmiana. Each plant produces approximately 1,500L of sap in a period of 4-6 months [4]. This can be consumed directly or as honey, which can be combined with other foods [5]. Its main components are water, sugars, proteins, gums, and mineral salts [4]. It is characterized by its high content of fructose and fructooligosaccharides, responsible for the prebiotic effect of this food [6]. On the other hand, the high content of saponins and phenolic compounds, contributes to attenuate glucose intolerance, weight reduction and fat mass, as well as lowering blood glucose, insulin and cholesterol levels [7]. It is also important to note that mead contains high levels of potassium, iron, B-complex vitamins, essential amino acids, and zinc [8].

\section{Xoconostle}

Xoconostle is a sour or bittersweet fruit produced by cacti, of the genus Opuntia spp. They are a good source of vitamins, amino acids, organic acids and betalains. The large number of bioactive compounds and nutrients make them perfect candidates for the production of health-promoting foods and supplements [9]. They present a high content of vitamin $\mathrm{C}$, surpassing the orange and strawberry, contains large amounts of fiber, minerals, and phenols, $100 \mathrm{~g}$ of the fruit contribute with $58 \%$ and $13 \%$ of the daily 
requirements of iron and zinc, respectively. Its antioxidant capacity exceeds that of strawberry, raspberry, red plum, grapefruit and orange [10]. Xoconostle has been reported to be rich in polyunsaturated (PUFAS) and saturated (SFA) fatty acids, ideal for providing cardiovascular benefits to the consumer; representative SFAs include ac. palmitic and myristic; monounsaturated fatty acids are ac. oleic and linoleic as the majority among PUFAS [11]. The usefulness of xoconostle has been described in the alternative treatment of type II diabetes mellitus (MD), reduction of triglycerides and cholesterol, since the hypoglycemic effect, its effect on the decrease of serum lipid levels and increase of insulin in blood [12].

\section{Garlic}

Garlic (Allium sativum) is known as a prophylactic therapeutic medicinal plant. It plays a dietary and medicinal role throughout the world. Many clinical and experimental studies mention the beneficial effects of garlic, mainly due to being a source of antioxidants such as flavonoids (quercetin and kaempferol), organosulfur compounds and their precursors (alliin, diallyl sulfide, allyl trisulfide and propyl sulfide) [13]; substances with antimicrobial effect for Gram positive, Gram-negative bacteria; acid-fast for the reduction of the risk of cardiovascular diseases, having a high impact on the reduction of cholesterol and triglycerides; likewise, reduction of the risk of cancer, such as the formation of DNA adducts, mutagenesis, elimination of free radicals, proliferation and cell differentiation, as well as angiogenesis; and mainly participating in the detoxification of foreign compounds and hepatoprotection [14].

\section{Conclusion}

The discernment of bioactive compounds and the desirable effects on consumer health are undoubtedly an indispensable instrument to reduce the incidence of chronic non-communicable diseases that in recent years have caused great economic costs and deaths throughout the world. Aguamiel, xoconostle and garlic are excellent options for obtaining bioactive compounds that can be included in the preparation of functional foods and even naturally integrated into the consumer's daily diet, as an alternative for healthy consumption.

\section{References}

1. Mera-Mamián AY, Tabares-González E, Montoya-González S, Muñoz-Rodríguez DI, Monsalve-Vélez F (2020) Recomendaciones de prácticas para evitar el desacondisionamiento físico durante el confinamiento por pandemia asociada a COVID-19. Univ Salud 22(2): 166-177.

2. Gutiérrez-Uribe JA, Figueroa LM, Martín-del-Campo ST, Escalante A (2017) Pulque. In: Frias J, Martinez-Villanueva C (Eds.), Fermented Foods in Health and Disease Prevention. Academic Press, USA, pp. 543556.

3. Ozen Asli E, Pons A, Tur AJ (2012) Worldwide consumption of functional foods: a systematic review. Nutrition Reviews 70(8): 472-481.

4. López-Varela S, González-Gross M, Marcos A (2002) Functional foods and the immune system: a review. European Journal of Clinical Nutrition 56(3): 529-533.

5. Alanís-Flores GJ, González-Álvarez M (2011) Formas de uso de los magueyes (Agave spp.) en Nuevo León. Rev Salud Pública y Nutr 5: 287-229.

6. Romero-López MR, Osorio-Díaz P, Flores-Morales A, Robledo N, Mora-Escobedo $\mathrm{R}$ (2015) Composición química, capacidad antioxidante y el efecto prebiótico del aguamiel (Agave atrovirens) durante su fermentación in vitro. Rev Mex Ing Quim 14(2): 281-292.

7. Leal-Díaz AM, Noriega LG, Torre-Villalvazo I, Torres N, Alemán-Escondrillas G, et al. (2016) Aguamiel concentrate from Agave salmiana and its extracted saponins attenuated obesity and hepatic steatosis and increased Akkermansia muciniphila in C57BL6 mice. Sci Rep 6(1): 34242.

8. Tovar-Robles CL, Perales-Segovia C, Cedillo AN, Valera-Montero LL, Gómez-Leyva JF, et al. (2011) Effect of aguamiel (Agave sap) on hematic biometry in rabbits and its antioxidant activity determination. Ital J Anim Sci 10(2): e21.

9. Arias-Rico J, Cruz-Cansino NS, Cámara-Hurtado M, López-Froilán R, Pérez-Rodriguez ML, et al. (2020) Study of Xoconostle (Opuntia spp.) Powder as Source of Dietary Fiber and Antioxidants. Foods 9(4): 403.

10. Gallegos-Vázquez C, Scheinvar L, Núñez-Colín CA, Mondragón-Jacobo C (2012) Morphological diversity of xoconostles (Opuntia spp.) or acidic cactus pears: a Mexican contribution to functional foods. Fruits $67(2)$ : 109-120.

11. Morales O, Barros L, Ramírez-Moreno E, Santos-Buelga C, Ferreira ICFR (2015) Xoconostle fruit (Opuntia matudae Scheinvar cv. Rosa) by- products as potential functional ingredients. Food Chemistry 185: 289-297.

12. Pimienta-Barrios E, Méndez-Morán L, Rmirez-Hernandez BC, García de Alba-García JE Domínguez-Arias RM (2007) Efecto de la ingestión del fruto de xoconostle (Opuntia joconostle Web.) sobre la glucosa y lípidos séricos. Agrociencia 42: 645-653.

13. Nieto G, Skidsted LH, Andersen ML, Ros G (2012) Actividad antioxidante y prooxidante del aceite esencial de ajo por resonancia de spin electrónica. An Vet 28: 23-33.

14. Ajami M, Vazirijavid R (2019) Garlic (Allium sativum L.). In: Mohammad NS, Sanches (Eds.), SA Nonvitamin and Nonmineral Nutritional Supplements. $1^{\text {st }}$ Edition, Academic Press, USA, pp. 227-234 